\title{
Class, Mothering and the Values of Food
}

\section{By Iben Charlotte Aamann}

\begin{abstract}
Class, Mothering and the Values of Food.

The data analysed in this empirical paper stems from ethnographic fieldwork among new school parents at three Danish primary schools. I draw on empirically grounded theories on the cultural and subjective dimensions of class, inspired by the 'English School' of poststructuralist informed, feminist scholars, to explore how class matters. Using the values ascribed to food at social arrangements as a lens, I explore different ways of doing class and mothering: through the exchange values of the food, through its use value and through its healthiness. I conclude by arguing that food studies hold a huge potential for the development of empirically grounded theories on class in Scandinavian society, where class hitherto has been ascribed as a thing of the past.
\end{abstract}

\section{KEYWORDS}

Class, mothering, food, parent-school relationships/

klasse, moderskab, mad, foreldre-skole relationer

Iben Charlotte Aamann has a degree in Danish and Gender Studies. She currently holds a PhD position at the Research Centre for Health Promotion on the Department of Psychology and Educational Studies at Roskilde University College, Denmark. Her research interests are parent-school relationships, health, gender and class. 


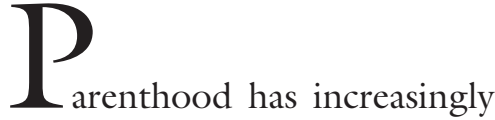

become a matter of public concern (Lee 2014; Ule et al. 2015; Geinger et al. 2013) and recent years have seen an intensification of the relations between the Danish comprehensive school and families which emphasise parent involvement as the way to a successful schooling (Dannesboe 2012; Knudsen 2010). This has been initiated through establishing local parent councils, organising a range of social events at schools and play groups in homes, and through expectations that the group of parents will meet in other contexts, both with and without the children, in order to become friends.

This article explores the doing of class and mothering through the food served at these social events. The ethnic Danish women analysed here all had a child starting in the final pre-school class in August 2013 at one of the three schools where I conducted ethnographic fieldwork that autumn/winter. However, they live very different lives due to differences in educational background and income.

Even though Denmark is rarely considered a class society (Faber et al. 2012), this article's point of departure is that class matters; not only for those at the bottom or the top of the social hierarchy, but also for those in between (Vincent \& Ball 2007). However, class understood as a lived everyday life experience is rarely explored in Denmark.

As food seems to be the signifier of class across Western societies (Anderson 2005; Moore 2013; Sandi Kawecka Nenga 2003) with its symbolic power to produce and mark social and cultural differences and similarities (Bourdieu 1984) and as food is central to family life as well as mothering (DeVault 1994), it is an obvious choice to use food as a lens through which I can explore the classed ways of doing mothering.

During the fieldwork, I participated in a range of the social events that constituted parent involvement. Here it occurred to me that there were quite different ways of doing 'good' parenting and rather diverse ideas about what doing 'good parenting' actually involved (Gillies 2007; Lareau 2011; Stefansen 2011). It also struck me that these differences were very apparent when viewed through food, as food played a role in almost all of the social events, from just a piece of fruit and a cup of water to big potluck buffets where each family brings a dish.

As it was primarily mothers who engaged in the practices surrounding food, this article explores how these women perform good mothering through the food at these events, analysing how the food is chosen, spoken of, legitimated and valued in different ways.

The main field of the article is the 'English school' (Hey 2003) of poststructuralist informed, feminist and empirical researchers (Walkerdine 1997; Mahony \& Zmroczek 1997; Skeggs 1997; Reay 1998), often concerned with the cultural and subjective dimensions of class in relation to education (Reay 1999, 2001, 2006; Gillies 2005; Reay et al. 2011) and parenting practices (Gillies 2005, 2007; Reay 1999, 2007; Reay et al. 2011; Walkerdine \& Lucey 1989).

I will begin with a description of the state of the art; here I also address the different fields of the article's position. After that, I will introduce my theoretical lens for viewing class, mothering and food. This will be followed by an account of the data production and analytical strategy. My analysis will then reveal three ways of doing mothering, leading on to a conclusion.

\section{StATE OF THE ART}

In both the UK and the US, scholars concerned with the classed and gendered di- 
mensions of motherhood polemically argue that the ideals of good parenting, promoted by schools and other institutions, such as health authorities, as neutral facts and common sense are actually white middleclass mothering practices being universalized (Gillies 2005; Landeros 2011; Perrier 2012; Reay 1999, 2005a). It is also argued that this springs from a history of institutionalised moral regulation and contempt of white working class femininity (Finch 1993; Walkerdine \& Lucey 1989; Skeggs 1997; Yeo 2005).

In Denmark, such a critique has not been launched (see Harrits 2014b). Though social differences are discreetly admitted, there is a strong sense of middleclassness and equality in Scandinavia (Faber et al 2014; Gullestad 1984; Lien et al. 2001). This might be one of the reasons why class, especially in Denmark, has been marginalised as an analytical tool. In recent years, however, there seems to have arisen a renewed interest in the cultural and subjective dimensions of class across Scandinavia (Bach 2011; Dahlgren \& Ljunggren 2013; Hansen 2014; Harrits 2014a; Murning 2013; Palludan 2012), in line with the interest of the present article.

Sociological food studies seem to be an expanding field of inquiry in Denmark, and especially media food is gaining attention (e.g. Leer 2014; Leer \& Kjær 2015; Povlsen 2012). However there is also a need for qualitative studies of everyday life practices surrounding food. Halkier provides such an account with a gender perspective (Halkier 2009 ; 2014), but without considering the cultural and subjective dimensions of class (although see Halkier 2010).

Sociological food studies related to public health issues are also growing in number. Several critics argue, however, that sociology in general, albeit unintended, often contributes to the symbolic production of class by misrepresenting people positioned low in the social hierarchy (Prieur \& Faber 2013; Bourdieu \& Ferguson 1999; Van
Galen 2004; Casey 2010). This might also be a risk to consider in food studies related to health issues, which are often concerned with the food consumption behaviour of 'the unhealthy' lower positioned people (e.g. Kamphuis et al. 2015; Wills et al. 2011). In contrast, this article offers another approach to class and health, inspired by the British researcher on class and gender, Beverley Skeggs (1997, 2004a), in which the complexities of class are taken into account, so that also people in a low position can be explored as having and producing value.

\section{THEORISING CLASS, MOTHERING AND FOOD}

In his influential work on cultural taste as class, Distinction, Bourdieu claims that the taste for specific foods - like other cultural objects such as music and art - is central to an understanding of class. He points to the ways in which the French upper and middle classes use the consumption of food to distinguish themselves from the lower classes (Bourdieu 1984), as: "Taste classifies, and it classifies the classifier" (Bourdieu 1984: 6).

However, there have been some crucial feminist critiques (Adkins 2004; Reay $2005 \mathrm{~b}$ ) of Bourdieu's pioneering work on class which I wish to consider. Firstly, a gender perspective should be taken into account and secondly, the critiques on the concept of habitus (Skeggs 2004a; 2004b; 2004c; 2005; 2009; 2011) are relevant here. Skeggs points out that habitus is only suitable for exploring the value accumulation of the privileged classes, and that we must therefore change our perspective to have any chance to notice the rather different kinds of values than the institutionalised middle-class ones, i.e. those being produced by and among people in a lower position. I will elaborate this perspective in dialogue with the data in the first two sections of the analysis.

In this article, I will explore how class is 
lived, not just spoken. Here, I am aligned with Reay who states that class is: "deeply embedded in everyday interactions, in institutional processes, in struggles over identity, validity, self-worth and integrity even when it is not acknowledged" (Reay 2005a: 924).

Seen in this light, class structures parenting in important ways. But since identity within the poststructuralist perspective is not retrospective reflections of objective social positions, class is not determinant, but rather constructed and performed in relation to gender, race, ethnicity and other social categories (Bettie 2003; Skeggs 1997; Lawler 2000; Trautner 2005).

Thus, when theorising class and motherhood as doings, the point is to stress their performative and intersecting character (hooks 1982; West and Zimmerman 2007); they are not fixed conditions with essential content, but rather intersecting social categories being constructed and negotiated while being performed (Butler 1999; Davies 2006).

I am interested in the values ascribed to the food when the women are doing mothering. Food on special occasions, like the social events I participated in during the fieldwork, is particularly relevant, as food before it is eaten sends a powerful signal about who one is, and who one would like to be (Fischler 1988). So: "the act of choosing, preparing and organising food has a role to play in communicating something about us to others" (Coveney, 2006: 24-25). Further, Julier suggests that at potlucks, due to the communal form of the meal, the food itself becomes the source of conversation, reflecting the identity and status of the person who cooked it (Julier, 2013: 147).

In general, all the food on the special occasions was homemade, in line with Halkier's point about the normativity of "the more homemade, the better"(Halkier, 2009: 358) and with the fact that the more preparation involved, the greater symbolic value the food contains, understood as a kind of gift to the community of families (Lupton, 1996: 48). However, as my analysis will reveal, the symbolic value ascribed to the food takes radically different forms.

It is well argued that food consumption habits serve to mark boundaries between social classes (Hoffman 2014). In fact, some researchers on food suggest that: "status, class, and prestige comprise probably the most important area signalled by food" (Anderson, 2005: 133; Sandi K. Nenga 2003).

The particular food on special occasions therefore makes an even more fruitful point of departure, as class rarely appears explicitly in Denmark, but rather infuses everyday life in quite subtle and indirect ways (Prieur \& Faber 2013).

Several scholars concerned with class, education and parenting practices (Reay, Crozier \& James 2011; Vincent \& Ball 2007) call for analytical attention to the fractions of the middle classes, which I am aligned with. That is why I use the plural form 'middle classes' and the terms 'vocationally trained' or 'lower positioned', 'of medium length education' (from the university colleges) and 'highly educated' (university degrees of $5+$ years) or 'privileged' when referring to the different positions within the middle classes.

\section{The Methods and Data Material}

In my ethnographic participant observations, I draw on 'from method to context' approaches (Denzin \& Lincoln 2005), emphasising the interactions between the researcher and the participants (Järvinen \& Mik-Meyer 2005). These non-restrictive approaches (Thuesen, Tanggaard \& Vitus, 2014:19) allow for conversations and interactions among the participants that are initiated by the researcher to be analysed as parts of the data produced. So what traditionally has been written off as irrelevant talk is in this perspective part of the data 
produced (Jensen 2009; Ringer 2013). Further, I consider everyday conversations as part of the data (Hollway \& Jefferson 2000).

I was present at the three primary schools (one independent school (friskole), one state school in Copenhagen proper and one state school just outside the capital) when the parents were at their first parents' meeting. Here I introduced my project and got to know them. The three groups of parents were slightly mixed, but with a majority of vocationally trained parents in the school outside Copenhagen, a majority of parents of medium length education at the friskole and parents with university degrees at the school in the city itself.

As far as possible, I extracted empirical data from the same kind of events in the three groups of parents. During the autumn and winter of 2013-14, I participated in four parents' meetings initiated by the schools and seven meetings held by the local parent councils in their homes, and also thirteen different social arrangements, e.g. parties at the schools and the affiliated institutions (after-school centres, playgrounds, etc.), playgroups and children's birthdays. I participated in six of those using multi-sited ethnography, following a family the whole day while they were preparing for the event. I also observed 15 home-school conferences and 21 enrolment conferences with the school nurses. In addition, I conducted ten individual walk and talk interviews with mothers, when they picked up their children in the afternoon, lasting from 30 minutes to $1 \frac{1 / 2}{2}$ hours, and semi-structured in-depth interviews with 6 mothers, lasting from $50 \mathrm{~min}$ utes to $2 \frac{1}{2}$ hours. I also gathered written material e.g. invitations and emails.

Besides the field notes, whenever something puzzled me, I wrote it down. An example was: Why were the bags of sweets loaded when the children of highly educated parents had a birthday party, while there was just one lollipop and some fruit and small toys in the bag for the children of the teaching couple?

As I ended up having a rather large amount of field notes and transcripts, I decided to use NVIVO in order to obtain a descriptive overview. A central feature of class, however, is that it is rarely mentioned explicitly, but rather appears as moral euphemisms (Bottero 2009) e.g. judgments about people using refined sugar or white wheat flour, etc. As class only gets worded indirectly, interpretations and associations are therefore needed to spot it (Skeggs, 2005: 965). For this reason, I began by coding the material in broad, empirical themes, e.g. 'leisure activities', 'talk about the school' and 'food'. After this coding, ending up with a large document about food, I left NVIVO and started to 'comb' the data with theories on class, health and gender, also revisiting my original field notes in order to analyse the data both longitudinally and transversely (Søndergaard 2000).

The analyses in this article are based on participant observations from three social events - one in each school - and informal everyday conversations I had with mothers in this context, as well as a parents' meeting. In the next three sections, I will elaborate on the analysis. It is not the individual women I am concerned with, but their different ways of doing motherhood through the food at the social events. In this sense, they might be considered as cases, as the three ways of doing motherhood may very well represent general patterns, although I did not deliberately seek to make this explicit (Flyvbjerg 2006).

\section{The Exchange Value of the Food}

In this part of the analysis we will join Marianne, a mother in her mid-30s. She holds a university degree, works as a middle manager in a large private enterprise and is actually the highest-earning female among all the participating parents. She lives with 
her husband, who also has a well-paying job, and their child in a fashionable part of Copenhagen - the primary school and after-school centre are only a few hundred yards away.

There is going to be a potluck at the after-school centre on Friday evening, and all the families will bring a dish of their choice to a large buffet. For a few days before the party, I meet with Marianne in the afternoons. We pick up her child at the afterschool centre and walk back to their house.

\section{DAY 1}

As I arrive at the after-school centre, Marianne is eagerly talking with the teachers about the party on Friday - about what kind of food they will have and something about "17 ounces of butter".

Pre-school teacher: "You better cut off a small slice and save it for me!" Marianne nods and smiles.

Afterwards I ask: "What is it we're contributing to the buffet on Friday?"

Marianne: “It's Liva [her daughter] who'd like me to make the Price Brothers' [I elaborate on the Price Brothers below] lemon moon cake. It contains 17 ounces of butter!”

\section{DAY 2}

The teachers are sitting around a table inside today. Marianne tells them about the cake again. One of them is very eager and says mock-threateningly that she must save her a piece. Marianne says that she already made arrangements with a co-worker yesterday for a separate cake especially for the staff. I say that I am also very excited about tasting the cake and we laugh a bit... On our way home we see a man on the opposite side of the road. His wife is one of the teachers at the after-school centre, Marianne quickly explains. She yells something to him across the road about his wife and about the Price Brothers' lemon moon cake. "Oh yes", he yells back: he has indeed heard about the cake and about how much his wife is looking forward to tasting it.

\section{The PARTy}

Last night while she was doing some work for her job, Marianne baked a small lemon moon cake for the staff and a big one for the buffet. Today, it arouses everyone's enthusiasm as people get around to trying it; several people make their way over to pay their compliments... I sneak up and grab a slice. It's delicious! I praise it. "After all, it DOES contain 17 ounces of butter," Marianne says.

What I find significant is the very central role of this cake in the days prior to the party, where Marianne eagerly talks about it on both days to all the people involved in the party, even yelling it across the street to the husband of one of the teachers. One effect of Marianne's enthusiasm is that the staff, the other parents and I get completely committed to her cake project.

The lemon moon cake might seem a rather spectacular cake, combined with the privileged affluent Marianne, due to its until recently, iconic status as a condensation of middle-class disgust with what is typically considered 'bad taste'. The cake's symbolic value as a euphemism for 'lower class' became clear through the 'lemon moon cake action' in November 2010 when more than 15,000 users registered on a Facebook protest page $\mathrm{i}^{\mathrm{i}}$ urging people to mail lemon moon cakes to the Danish People's Party as a satirical comment on one of the leaders' anti-immigrant statements.

However, I would argue that it is exactly this cake that enables Marianne to gain positive attention, and thereby also accrue value to herself. This is because of what I suggest to be the exchange value of the lemon moon cake, as exchange value no longer is based solely on the relations of 
production, but now also on the use of culture from which values can be extracted (Skeggs, 2004b: 77).

In recent years, the lemon moon cake has gained a huge symbolic value as 'kitsch'. In 2011 the celebrity chefs The Price Brothers rebranded the lemon moon cake in one of their cookbooks as well as on their television show Eat with Price. The Price Brothers recurrent theme is playing with traditional class and gender connotations (Leer 2014) and celebrating food that does not fit with the official dietary recommendations.

So when Marianne is able to make an outright gimmick out of her contribution to the potluck, it is because of this rebranding and exchange value of the cake. This becomes clear when Marianne emphasises that it is The Price Brothers' lemon moon cake.

The Price Brothers inscribe themselves in "the omnivorous taste ideal of our time" (Leer, 2014: 182), which is often highlighted as a sign of the death of the classes, as it seems that traditional class distinctions are being broken down when the middle classes re-evaluate culture that is traditionally associated with the working class (Peterson \& Kern 1996).

However several critics have argued that the omnivorousness - rather than leading to a breakdown - works through a redrawing of cultural class boundaries: not only because it capitalises culture, but also because of its selectivity whereby it becomes exclusionary (Warde et al. 2000). Therefore the omnivore self actually rather enhances class divisions although in subtle and diffuse ways (Skeggs 2004c), which also in Scandinavia (Jarness 2013) - enable the occurrence of new upper-middle class configurations around self-reflexivity.

In line with this, Marianne was, at the party, telling about her troubles with the icing: to get the right yellow fruit colour, she had to go to a special store: "It wouldn't really work with turmeric, which is too dark yellow". These considerations reveal how much selectivity and reflexivity is involved in the lemon moon gimmick: even a nuance has to be the right one, no matter how difficult to get or how expensive.

The selectivity was also revealed when Marianne discovered that her fingertips were yellow from the fruit colour: "Oh my God, it really looks like I smoke!" she laughed several times, creating a witty distance to smoking. Precisely smoking seems to be yet another euphemism for class (Graham 2012), but manifestly not one to extract value from.

Marianne's gimmick with the lemon moon cake and the choice of it as their 'family cake' (cf. the fact that the daughter wanted it for the potluck), proves her reflexive ability to select a traditionally lowerclass icon and extract its exchange value.

Marianne's way of doing mothering seems to fit perfectly with Bourdieu's concept of habitus, which is about having a "feel for the game" (Bourdieu, 1990: 66): as the privileged Marianne knows how to 'play it', the gimmick on the potluck contribution works as a way for her to accumulate value.

In this sense, habitus is an apt theory about the privileged, as it relies on an engagement with the imperative (of 'the game') to maximise one's value (Skeggs, 2004c: 85). But in my study, it was far from all mothers who charged themselves with value in Marianne's playful way, and also Skeggs' empirical research (Skeggs \& Wood 2012; Skeggs 1997, 2005) on class shows that not everyone plays that game. So what the concept of habitus cannot explain is "the non-propelling future-accruing subject ... those who cannot access the fields of exchange to convert, accrue or generate value for themselves" (Skeggs, 2011: 502).

Bourdieu argues further that in contrast to the upper and middle classes' food consumption, the lower classes develop a habitus around "a taste for necessity" (Bourdieu, 1984: 373). So with the toolbox of 
Bourdieu, Skeggs writes: "these subjects appear with negative capital, as lack, deficit, a void of value..." (ibid.).

In order to avoid the risk of misrepresenting and lacking understandings in the study of the lower positioned people, I therefore have to shift perspective to catch sight of and explore their production of value. I will elaborate on the relevant perspectives in the next section of the analysis.

\section{The Use Value of the Food}

In this part of the analysis we will join Celine, a vocationally trained mother in her early 30s, who lives with her husband (technician) and their two children in a villa from the 1970s in a small town in Zealand. At an afternoon Christmas event for all the families, organised by the parent council of the pre-school class and held at the local school, Celine chose to make 350 Danish ableskiver herself.

From my field notes:

Celine (works as an office clerk) just made 350 æbleskiver for the event. They are stacked in a mountain of freezer bags on the counter in the home economics room. "Hey, it wasn't a big deal," she says modestly as I am visibly impressed. Dorthe had a lot of frozen berries left over from her birthday - well, Celine got to take those home, so she also made some jam. The strawberry and raspberry jams stand on a rack in shiny black jars with patented lids. Celine explains: she thinks that homemade xbleskiver taste a lot better than the ones you buy in stores. And it's cheaper, too...

Celine is much more restrained and modest about the ebleskiver and the jam than Marianne, for whom the lemon moon cake was the central topic of conversation during the days up to the party.

What I would argue here is that this is a radically different kind of value Celine ascribes to her contribution than that of the privileged mother; because during our subsequent talk, she emphasises superior taste and the competitive price as reasons for taking on the huge amount of work. The value which Celine assigns to the food is thus far from the same exchange value as Marianne's lemon moon cake. I would argue that this is because Celine does not 'play the game' of value accrual through highlighting her 'gift' to the community as Marianne did.

But is this really a matter of a habitus, developed around 'the taste of necessity' as Bourdieu's approach would find? When Celine's ebleskiver testify to a radically different way of doing mothering than Marianne's, how can I grasp Celine's production of value?

I suggest that it is a matter of use value. By this I am referring to a way of "thinking beyond exchange-value, instead through use-values that do not rely ... on a concept of accumulative subjectivity [like habitus], which is always reliant on exchange-value" (Skeggs, 2004c: 89).

When Celine points to the price and the better taste of the homemade ableskiver, it is precisely their use value she highlights. Likewise, when she and I talk about the preparation of the Danish ebleskiver, she focuses on something radically different than Marianne:

Celine tells me that the other night the dog started barking at $4 \mathrm{am}$. She woke up and couldn't go back to sleep, so she got out of bed and started making xbleskiver! Then the youngest child entered the kitchen. He had woken up. Well, up on the stool he goes to join the party! So there they were in the middle of the night making xbleskiver! Both her boys, she continues, love being involved in kitchen 
activities, and always have. So they each have a stool which kind of follows along the kitchen counter, she laughs.

Celine is preoccupied with the intimate relations tied to the ableskiver preparation process which works as an occasion for contact with her youngest child - it is the time she spent with her son that she chooses to highlight to me. For the privileged mother it was different: to Marianne the preparation rather seemed like something to get over with, as she made the cake while working late at night after her daughter had gone to bed.

Besides the shift in focus from habitus and exchange value to use value when exploring lower positioned people, I would also suggest considering the way time and energy do not get invested in the self, but rather are given to others. In this way, it is possible to grasp how these value practices are made "not (just) through self-value accrual but through the gift of attention to others" (Skeggs, 2011: 508).

With this perspective, I can grasp how Celine actually produces value via the 'gift of attention' and the time and energy she puts into the Danish ebleskiver: because they taste better and because they are cheaper, she wants to make them herself instead of buying them: Celine is giving her time and energy to the other families. In contrast, Marianne's lemon moon cake rather seemed to be an investment in herself.

\section{The Healthiness of The FoOd}

In contrast to the privileged mother's exchange value and the lower positioned mother's use value, the following two mothers, positioned somewhere in between with education of medium length, were occupied with the healthiness and the moral implications of the food served on the special occasions.

At a potluck on a Sunday afternoon held in a playground close to the friskole, no sweets were served. Kirsten, a teacher in her forties with two children, lives in a flat in town with her husband, also a teacher. When asked about her contribution, she explained: "We brought along homemade rye bread because I was going to bake anyway ... and melon and carrots, because I think there should be vegetables and fruit available during and after the meal". Kirsten is aware that unhealthy food might be served, so she planned to make sure that there would be healthier food on offer among the dishes.

This way of doing mothering seems to be charged with morals, which is also expressed in the following example: the scene is a parents' meeting at the school outside Copenhagen. This piece of data differs from the other ones analysed, as it is not a festive event and as it is not the mother and I who talk. Although the situation is different and positions the parents differently, it adds a point to the analysis, as the parents here are considering rules about what food to serve at a particular kind of social event, namely when celebrating children's birthdays.

A mother, Sofie (school teacher), asks whether there are rules for the distribution of sweets on birthdays.

The teacher: “There aren't any rules, they can pass around whatever they want even marshmallow treats".

Sofie says doubtfully: "It's just that we're not used to that in the kindergarten, there it had to be more...classy food, if one can put it like that".

Interestingly Sofie does not use the word 'healthier', but instead calls it 'classy'. This reveals how food here is charged with morality. In line with Kirsten, then, Sofie seems to be doing mothering by taking on a moral responsibility for the healthiness of the food served.

When Sofie and Kirsten are doing moth- 
ering through the 'right', institutionalised moral standards - in contrast to Marianne's playful, self-reflexive value accumulation, or Celine's focus on the use value - they seem to be doing 'proper mothering'. This then can be explained as an attempt to distinguish themselves from lower positioned people, which, with the concept of habitus, should be explained as a feel for the game in line with the privileged mother. But I would argue that this game is quite different: whereas Marianne was occupied with accumulating further value, these two mothers seem more concerned about protecting their status (Skeggs 1997). This leads me to suggest that Sofie and Kirsten's distinctive approach might spring from a position in "the squeezed middle" (Reay et al., 2011: vii) and an anxiety arising from a "fear of falling" (Ehrenreich 1989), i.e. of being deemed lower-class mothers.

In contrast, the privileged mother did not seem to worry about health issues related to her chosen food. In fact, this 'carefree' attitude was almost demonstrative when Marianne several times stressed the amount of butter required for the Price Brothers lemon moon cake. Actually, it was not until I posted a question to the whole group of parents via e-mail about the buffet food that I found out that the family had also brought a green salad for the buffet.

Marianne thus did not seem to consider healthy food as something to extract value from. On the contrary, she positioned herself as superior to moral judgments, entitled to suspend the imperative of health without running the risk of being judged as a lower-class mother. This could be explained as a class distinction towards the medium educated mother's need to do proper mothering. As argued, Celine seemed orientated towards some radically different value practices in which close relations and a different form of attention were present, as time and energy was given to others, not invested in the self.

\section{CONCLUSION}

In this article, I have explored three ways of doing class and mothering through the values of food on special occasions, in the context of intensified relations between parents and schools. Firstly, a privileged way of doing mothering through extracting the exchange value of the food and thereby accumulating value for oneself. Secondly, a lower positioned focusing on the use value of the food, and finally an 'in between' way of doing proper mothering through taking on a moral responsibility for the healthiness of the food.

I have argued that the 'in between' mothers drawing on correctness and health standards might stem from an anxiety of been morally judged as lower class mothers. In contrast to this, I have argued that the privileged mother seems to distinguish herself from precisely this by showing off her mandate to suspend moral judgments. Further, I have argued that the lowest positioned mother seems to be oriented towards radically different value practices.

This is not to say in general that only mothers in the middle of the middle classes are concerned with the healthiness of food. Rather, I argue that at the social events analysed in this article, health seemed central and that this was in contrast to both the highly and lowly educated mothers' ways of doing mothering through food.

I have employed a range of British perspectives on Bourdieu's tools, designated to prevent a sociological tendency to misrepresent people from the lower classes. However it is not without problems to apply British perspectives to a Danish context: in Denmark, class would appear to manifest itself differently than in England, where society is more powerfully stratified and where class inequalities are therefore subject to greater awareness in research, politics and the general public. Also the practises of mothering might configure different due to the cultural diversity between the 
countries, about what doing good mothering actually involves.

There is, therefore, a need to develop theoretical concepts that can capture the cultural and subjective dimensions of class in relation to gender and parenting in a Scandinavian context, where class until recently seemed linguistically expunged. By extension, I argue that food studies holds a huge potential for the development of empirically grounded theories on these issues.

\section{Notes}

1. http://videnskab.dk/kultur-samfund/citronmane-aktion-er-virkningslost-rygklapperi Last visit: 03.09.2015

\section{LITERATURE}

- Adkins, Lisa (2004): Introduction, Context and Background, in: L. Adkins and B. Skeggs (eds.): Feminism After Bourdieu. The Editorial Board of the Sociological Review: Blackwell Publishing, Oxford.

- Anderson, Eugene N. (2005): Everyone Eats: Understanding Food and Culture. New York University Press, New York and London.

- Bach, Dil (2011): Overskudsfamilier - Om Opdragelse, Forbundethed Og Grensesetning Blandt Velstående Familier I Danmark. Aarhus University, København.

- Bettie, Julie (2003): Women Without Class: Girls, Race and Identity. University of California Press, California.

- Bottero, Wendy (2009): Class in the 21st Centu$r y$, in: K. P. Sveinsson (eds.): Who Cares about the White Working Class? Runnymede Perspectives. - Bourdieu, Pierre (1990): The Logic of Practice. Stanford University Press, Stanford.

- Bourdieu, Pierre (1984): Distinction: A Social Critique of the Judgement of Taste. Harvard University Press, Cambridge/Mass.

- Bourdieu, Pierre and Ferguson, Priscilla Parkhurst (1999): The Weight of the World: Social Suffering Incontemporary Society. Polity Press, Stanford.
- Butler, Judith (1999): Gender Trouble Feminism and the Subversion of Identity. Routlegde, New York.

. Casey, Emma. 2010. Struggle and Protest or Passivity and Control? The Formation of Class Identity in Two Contemporary Cultural Practices, in: European Journal of Cultural Studies 2000/ $13(2)$.

- Coveney, John (2006): Food, Moral and Meanings -The Pleasure and Anxiety of Eating. Routlegde, London.

- Dahlgren, Kenneth and Ljunggren, Jørn (2013): Klassebilder - Ulikbet Og Sosial Mobilitet I Norge. Universitetsforlaget, Oslo.

- Dannesboe, Karen Ida (2012): Hvem Sagde Samarbejde? Aarhus Universitetsforlag, Aarhus.

- Davies, Bronwyn (2006): Subjectification: The Relevance of Butler's Analysis for Education, in: British Journal of Sociology of Education 2006/27(4).

- Denzin, Norman K. and Lincoln, Yvonna S. (2005): The SAGE Handbook of Qualitative Research. Sage Publications, New York.

- DeVault, Majorie (1994): Feeding the Family: The Social Organization of Caring as Gendered Work. University of Chicago Press, Chicago.

- Ehrenreich, Barbara (1989): Fear of Falling: The Inner Life of the Middle Class. Pantheon Books, New York.

- Faber, Stine T. (red) (2014): Nye Tider - Nye Klasseskel?, in C. S. Hansen (eds.): Socialt rum, symbolsk magt - Bourdieuske perspektiver på klasse. Hexis, København.

- Faber, Stine Thidemann, Prieur, Annick, Rosenlund, Lennart, and Skjøtt-Larsen, Jakob (2012): Det skjulte klassesamfund. Aarhus Universitetsforlag, Aarhus.

- Finch, Lynette (1993): The Classing Gaze: Sexuality, Class and Surveillance. Allen \& Unwin, St. Leonards, NSW.

- Fischler, Claude (1988): Food, Self and Identity, in: Social Science Information 1988/27(2).

- Flyvbjerg, Bent (2006): Five Misunderstandings About Case-Study Research, in: Qualitative Inquiry 2006:12(2).

- Van Galen, Jane A. (2004): Seeing Classes: Toward a Broadened Research Agenda for Critical Qualitative Researchers, in: International Journal of Qualitative Studies in Education 2015/17.

- Geinger, Freia, Vandenbroeck, Michel and Roets, Griets (2013): Parenting as a Performance: Parents as Consumers and (de)constructors of Mythic Parenting and Childhood Ideals, in: Childhood $2013 / 21(4)$. 
. Gillies, Valerie (2005): Raising the 'Meritocracy': Parenting and the Individualization of Social Class in: Sociology 2005/39(5).

- Gillies, Valerie (2007): Marginalised Mothers Exploring Working-Class Experiences of Parenting. Faculti, London/New York.

. Graham, Hilary Mavis (2012): Smoking, Stigma and Social Class, in: Journal of Social Politics 2012/4l(1)

- Gullestad, Marianne (1984): Kitchen-Table Society - A Case Study of the Family Life and Friendships of Young Working-Class Mothers in Urban Norway. Universitetsforlaget, Olso.

- Halkier, Bente (2009): Suitable Cooking?: Performances and Positionings in Cooking Practices among Danish Women, in: Food, Culture and Society 2009/12(3).

- Halkier, Bente. 2010. Consumption Challenge: Food in Medialised Everyday Lives. Ashgate, Burlington.

- Halkier, Bente (2014): Contesting Food - Contesting Motherhood? in: S. O' Donohoe, M. Hogg, P. Maclaran, L. Martrns, and L. Stevens (eds.): Motherhood, markets and consumption: The making of mothers on contemporary Western cultures. Routledge, New York.

- Hansen, Christian Sandbjerg (eds.) (2014): Socialt Rum, Symbolsk Magt. Hexis, København.

- Harrits, Gitte Sommer (2014a): Klasse - En Introduktion. Hans Reitzel, København.

- Harrits, Gitte Sommer (2014b): Klasse Og Kategori - En Analyse Af Symbolske Hierarkier I Dansk Forebyggelsespolitik, in C. S. Hansen (eds.): Socialt rum, symbolsk magt - Bourdieuske perspektiver på klasse. Hexis, København.

- Hey, Valery (2003): Joining the Club? Academia and Working-Class Femininities, in: Gender and Education 2003/15.

- Hoffman, Brigid (2014): Food and the Performance of Social Class. The University of South Dakota, Dakota.

- Hollway, Wendy and Jefferson, Tony (2000): Doing Qualitative Research Differently. Sage Publications, New York.

- hooks, bell (1982): Aint I a Woman? Black

Women and Feminism. Pluto Press, London. - Jarness, Vegard (2013): Class, Status, Closure The Petropolis and Cultural Life. University of Bergen, Bergen.

- Jensen, Sune Qvotrup (2009): “Er Det Noget Med Bander?", in: Dansk sociologi 2009/20 (1). - Julier, Alice P (2013): Eating Together Food, Friendship, and Inequality. University of Illinois Press, Urbana.
- Järvinen, Margaretha and Mik-Meyer, Nanna (2005): Kvalitative Metoder I Interaktionistisk Perspektiv. Hans Reitzels forlag, København.

- Kamphuis, Carlijn, Jansen, Tenna, Mackenbach, Johan and van Lenthe, Frank (2015:) Bourdieu's Cultural Capital in Relation to Food Choices: A Systematic Review of Cultural Capital Indicators and an Empirical Proof of Concept, in: PLoS One $2015 / 10(8)$.

- Knudsen, Hanne (2010): Har vi En Aftale? Nyt fra Samfundsvidenskaberne, København.

- Landeros, Mary (2011): Defining the 'good Mother' and the 'professional Teacher': Parentteacher Relationships in an Affluent School District, in: Gender and Education 2011/23(3).

- Lareau, Annette (2011): Unequal Childhoods Class, Race, and Family Life. University of California Press, Berkeley, Los Angeles \& London.

- Lawler, Steph. (2000): Mothering the Self: Mothers, Daughters, Subjects. Routledge, London, New York.

- Lee, Ellies, Bristow, Jennie, Faircloth, Charlotte and Macvarish, Jan (2014): Parenting Culture Studies. Palgrave Macmillan, Basingstoke.

- Leer, Jonatan and Meldgaard Kjær, Katrine (2015): Strange Culinary Encounters, in: Food, Culture os Society 2015/18(2).

- Leer, Jonathan (2014): Ma(d)skulinitet-Maskulinitetskonstruktioner I Europeiske Madprogrammer Efter The Naked Chef I Lyset Af'den Maskuline Krise'. Københavns Universitet, København. - Lien, Marianne E., Lidén,Hilde and Vike, Halvard (2001): Likhetens Paradokser. Universitetsforlaget, Oslo.

- Lupton, Deborah (1996): Food, the Body and the Self. Sage Publications, New York.

- Mahony, Pat. and Zmroczek, Christine (ed.) (1997): Class Matters: 'Working-Class' Women's Perspectives on Social Class. Taylor \& Francis, London; Bristol, PA.

- Moore, Susanne (2013): Food Is Now the Ultimate Class Signifier, in: The Guardian. Retrieved (http://www.theguardian.com/commentisfree/2 $013 / \mathrm{mar} / 27$ /food-class-poor-people-stamps).

- Murning, Susanne (2013): Social Differentiering Og Mobilitet I Gymnasiet - Kulturel Praksis, Sociale Positioner Og Mulighed for Inklusion. Aarhus Universitet, Aarhus.

- Nenga, Sandi K. (2003): Social Class And Structures Of Feeling In Women's Childhood Memories Of Clothing, Food, And Leisure, in: Journal of Contemporary Ethnography 2003/32(176).

- Palludan, Charlotte (2012): Skolestart - et Følsomt Forældrearbejde, in: K. I. Dannesboe, N. 
Kryger, C. Palludan, and B. Ravn (eds.): Hvem sagde samarbejde? Et hverdagslivsstudie af skolehjem relationer. Aarhus Universitetsforlag, Aarhus. - Perrier, Maude (2012): Middle-Class Mothers' Moralities and 'Concerted Cultivation': Class Others, Ambivalence and Excess, in: Sociology 2012/47(4).

- Peterson, Richard A. and Kern, Roger M. (1996): Changing Highbrow Taste: From Snob to Omnivore, in: American Sociological Review 1996/61(5).

- Povlsen, Karen Klitgaard (2012): Fra Kogebog Til Madblog : Julie and Julia (2009) Og Mastering the Art of French Cooking, in: Aktuel forskning ved Institut for Litteratur, Kultur og Medier 2012/2(1).

- Prieur, Annick and Faber, Stine T (2013): Sociologish Arbejdspapir Class in Disguise: On Representations of Class in a Presumptively Classless Society. Aalborg Universitet, Aalborg.

- Reay, Diana (1999): Linguistic Capital and Home-School Relationships: Mothers' Interactions with Their Children's Primary School Teachers, in: Acta Sociologica 1999/42(2).

- Reay, Diane (1998): Rethinking Social Class: Qualitative Perspectives on Class and Gender, in: Sociology 1998/32(2).

- Reay, Diane (2001): Finding or Losing Yourself?: Working-Class Relationships to Education, in: Journal of Education Policy 2001/16(4).

- Reay, Diane (2005a): Beyond Consciousness?: The Psychic Landscape of Social Class, in: Sociology 2005/39(5).

- Reay, Diane (2005b): Gendering Bourdieu's Concepts of Capitals? Emotional Capital, Women and Social Class, in: The Sociological Review2005/ 52 .

- Reay, Diane. 2006. The Zombie Stalking English Schools, in: British Journal of Educational Studies 2005/54(3).

- Reay, Diane (2007): 'Unruly Places': Inner-City Comprehensives, Middle-Class Imaginaries and Working-Class Children, in: Urban Studies $2007 / 44(7)$.

- Reay, Diane, Crozier, Gill and James, David (2011): White Middle-Class Identities and Urban Schooling. Palgrave Macmillan, New York Houndmills, Basingstoke, Hampshire.

- Ringer, Agnes (2013): Researcher-Participant Positioning and the Discursive Work of Categories: Experiences from Fieldwork in the Mental Health Services. Qualitative Studies 2013/4(1). - Skeggs, Bev (1997): Formations of Class and Gender: Becoming Respectable. Thousand Oaks, California. Sage Publications, London.
- Skeggs, Bev (2004a): Class, Self, Culture. Routledge, London.

- Skeggs, Bev (2004b): Context and Background : Pierre Bourdieu 'S Analysis of Class, in: Gender and Sexuality. (January 2002).

- Skeggs, Bev (2004c): Exchange, Value and Affect: Bourdieu and 'the Self', in L. Adkins and B. Skeggs (eds.): Feminism After Bourdieu. The Editorial Board of the Sociological Review: Blackwell Publishing Ltd, Oxford:

- Skeggs, Bev (2005): The Making of Class and Gender through Visualizing Moral Subject Formation, in: Sociology 2005/39(5).

- Skeggs, Bev (2009): The Moral Economy of Person Production: The Class Relations of Self-Performance on 'reality' Television, in: The Sociological Review 2009/57(4).

- Skeggs, Bev (2011): Imagining Personhood Differently: Person Value and Autonomist WorkingClass Value Practices, in: The Sociological Review 2011/59(3).

- Skeggs, Bev and Wood, Helen (2012): Reacting to Reality Television: Performance, Audience and Value. Routledge, New York.

- Stefansen, Kari (2011): Foreldreskap I Småbarnsfamilien Klassekultur Og Sosial Reproduksjon. NOVA - Norsk Institutt for Forskning om Oppvekst, Velferd og Aldring, Oslo.

- Søndergaard, Dorte (2000): Destabiliserende Diskursanalyse : Veje Ind I Poststrukturalistisk Inspireret Empirisk Analyse, in Haavind, Hanne (eds.): Kjønn og fortolkende metode: metodiske muligheter $i$ kvalitativ forskning. Oslo.

- Thuesen, Frederik, Tanggaard,Lene and Vitus, Kathrine (2014): Konflikt I Kvalitative Studier. Hans Reitzel: København.

- Trautner, Mary Nell (2005): Doing Gender, Doing Class: The Performance of Sexuality in Exotic Dance Clubs, in: Gender er Society 2005/19(6). - Ule, Mirjana, Živoder, Andreja and du Bois-Reymond, Manuela (2015): 'Simply the Best for My Children': Patterns of Parental Involvement in Education, in: International Journal of Qualitative Studies in Education 2015/28.

- Vincent, Carol and Ball, Stephen (2007): ' Making up ' the Middle Class Child: Families, Activities and Class Dispositions, in: Sociology 2007/4l(6).

- Walkerdine, Valerie (1997): Daddys Girl. Macmillan, London.

- Walkerdine, Valerie and Lucey, Helen (1989): Democracy in the Kitchen: Regulating Mothers and Socialising Danghters. Virago, London.

- Warde, Alan, Tomlinson, Mark, Mcmeekin, Andrew and Lupton Suite, Tom (2000): Expanding 
Tastes ?: Cultural Omnivorousness \& Social Change in the Uk, in: CRIC Discussion Paper $2000 / 37$.

- West, Candace and Zimmerman, Don H. (2007): Dong Gender, in: Gender and Society 2007/1(2). . Wills, Wendy, Backett-Milburn, Kathryn,
Roberts, Mey Li and Lawton, Julie (2011): The Framing of Social Class Distinctions through Family Food and Eating Practices, in: Sociological Review 2011/59.

· Yeo, Eileen (2005): Constructing and Contesting Motherhood, 1750-1950, in: Hecate 2005/31. 